\title{
PENINGKATAN HASIL BELAJAR MENULIS TEKS PROCEDURE MELALUI MODEL PEMBELAJARAN SCRAMBLE TEXT SISWA
}

\author{
Dyah Wulandari ${ }^{1)}$ \\ 1) SMP Negeri 2 Tugu \\ wuwukwulandari@gmail.com
}

\begin{abstract}
ABSTRAK: Permasalahan yang dihadapi peneliti selaku guru kelas IX di semester 1 hampir selalu sama, yaitu kemampuan menulis. Khususnya pada teks Procedure, padahal mereka sudah mempelajarinya di kelas VII. Oleh karena agar tidak terulang, maka pada awal tahun ajaran 2015/2016 peneliti selaku guru kelas IX SMP Negeri 2 Tugu melakukan penelitian dengan menerapkan model pembelajaran yang berbeda, yaitu Scramble text. Kelas IX A dipilih dengan pertimbangan bahwa pada prestasi belajar menulis kelas ini adalah yang paling rendah pada saat kelas VIII pada KD menulis, dengan ketuntasan klasikal 55,56\%. Penelitian ini dirancang dalam 2 siklus dan 4 tahap. Hasil dari penelitian ini adalah peningkatan nilai rata-rata yang pada saat prasiklus adalah 63,89 dan meningkat menjadi 73,75 pada siklus 1 . kemudian pada siklus 2 meningkat lagi menjadi sebesar 79,72. Begitu pula dengan persentase ketuntasan kelas yang meningkat dari $55,56 \%$ pada prasiklus menjadi menjadi $72,22 \%$ pada siklus 1 dan $91,67 \%$ pada siklus 2 .
\end{abstract}

Kata kunci : Hasil Belajar, Teks Procedure, Scramble Text

ABSTRACT: As an English teacher of ninth grade, the problem faced is almost the same. It is about the students' ability on writing, especially procedure text. It must not be occured because the students has learnt it in 7th grade. That is why in the beginning of the academic year of 2015/2016 the action research is held to overcome the problem by implementing Scramble Text in teaching English. Class IX A is chosen by considering that the achievement of this class is the worst among other classes of the eighth grade. The classical mastery on wrting is 55,56\%. The research is designed in two cycles and four stages. After analysing the data it can be concluded that the students' average is increased from 63,89 in pre cycle into 73,75 in first cycle. It becomes 79,72 in second cycle. The precentage of classical mastery is also increased from 55,56\% during pre cycle into $72,22 \%$ in the first cycle. It become $91,67 \%$ in second cycle.

Keywords: Sudents' Achievement, Procedure Text, Scramble Text

\section{PENDAHULUAN}

Pada tahun pelajaran 2015/2016 SMP Negeri 2 Tugu masih menggunakan Kurikulum Tingkat Satuan Pendidikan tahun 2006. Berdasarkan pengamatan peneliti selaku guru kelas IX disetiap pembelajaran menulis teks Procedure hampir selalu menemui kesulitan. Padahal pada kegiatan pembelajaran KD sebelumnya yakni KD 5 pada pembelajaran reading tidak ada masalah yang berarti. Di dalam kegiatan pembelajaran reading, siswa sudah diberi bekal pengetahuan tentang teks yang dipelajari, unsur-unsur kebahasaan dan fungsi sosial. Banyak siswa yang nilainya dibawah ketuntasan minimal, sehingga peneliti harus mengadakan pembelajaran remidi yang kadang tidak hanya sekali agar target ketuntasan klasikal sering terpenuhi. Seharusnya masalah initidak perlu muncul karena teks Procedure sudah dikenalkan pada siswa ketika mereka kelas VII semester 2. 
Permasalahan-permasalahan tersebut dimungkinkan karena rendahnya kemampuan keterampilan menulis siswa. Banyak siswa mengalami kendala dalam menuangkan fikiran mereka dalam bentuk tulisan. Mereka bingung tentang apa yang akan ditulis walaupun itu mengenai kehidupan mereka sehari-hari. Atau kemungkinan cara mengajar guru yang tidak bervariasi dan terlalu banyak ceramah. Selain itu kemungkinan guru juga hanya mengandalkan buku pendamping siswa saja dan tidak memberikan latihan-latihan yang dapat menunjang kemampuan menulis siswa.

Agar kejadian tersebut tidak terjadi lagi, maka pada awal tahun pelajaran 2015/2016 peneliti akan mencoba menerapkan cara yang berbeda dari tahun-tahun sebelumnya. Untuk itu peneliti berdiskusi dengan guru bahasa Inggris pengampu kelas VIII tentang pencapaian setiap kelas khususnya pada keterampilan menulis. Pada akhir semester 2 kelas VIII keterampilan menulis yang harus dikuasai adalah menulis teks narrative. Dari hasil diskusi diketahui bahwa kelas VIII A adalah kelas dengan pecapaian terendah bila dibandingkan dengan 7 kelas lainnya. Dari 36 siswa hanya 55,56\% atau 20 siswa bisa mencapai nilai Kriteria Ketuntasan Minimal.

Peneliti memilih model pembelajaran Scramble Text karena diharapkan akan dapat memberikan siswa sebuah pengalaman belajar yang menyenangkan dengan bekerja sama dalam menyusun teks yang sebelumnya sudah diacak. Agar lebih menarik maka potongan-potongan kalimat itu dicetak pada kertas kecil-kecil yang kemudian akan mereka tempelkan pada kertas karton tebal (kertas duplex). Dan dengan bekerja secara kelompok diharapkan akan terjalin kerjasama yang baik dan pertukaran fikiran sehingga akan semakin bisa membuka wawasan mereka.

Oleh karena itu dalam penelitian tindakan kelas ini, judul yang dipilih oleh peneliti adalah "Peningkatan Hasil Belajar Menulis Teks Procedure Melalui Model Pembelajaran Scramble Text Siswa Kelas IX A Semester 1 Tahun Pelajaran 2015/2016 di SMP Negeri 2 Tugu Kabupaten Trenggalek". Berdasarkan paparan yang diatas, maka rumusan masalah pada kegiatan penelitian ini adalah: "Bagaimanakah peningkatan hasil belajar menulis teks procedure melalui model pembelajaran Scramble Teks siswa kelas IX A Semester 1 tahun pelajaran 2015/2016 di SMP Negeri 2 Tugu Kabupaten Trenggalek?" Sesuai dengan permasalahan penelitian di atas, maka penelitian ini bertujuan untuk memberikan deskripsi yang akurat tentang peningkatan hasil belajar menulis teks Procedure melalui model pembelajaran Scramble Teks siswa kelas IX A Semester 1 tahun pelajaran 2015/2016 di SMP Negeri 2 Tugu Kabupaten Trenggalek.

Hasil dari penelitian ini, nantinya diharapkan akan memberikan manfaat bagi berbagai pihak diantaranya bagi siswa diharapkan dapat mengatasi kesulitan mereka dalam mengarang teks Procedure pendek sederhana dan meningkatkan hasil belajar siswa kelas IX khususnya kelas IX A Semester 1 tahun pelajaran 2015/2016 dalam mempelajari Bahasa Inggris. Manfaat yang diharapkan dapat peroleh oleh guru hendaknya dapat dijadikan tolak ukur bagi keberhasilann dalam kegiatan pembelajaran Bahasa Inggris 
sehingga akan mampu mengadakan perbaikan dalam mengelola kegiatan Pembelajarannya di masa mendatang, dapat digunakan sebagai saran untuk kegiatan Pengembangan Keprofesian Berkelanjutan dan Bagi para praktisi pendidikan (guru) lain, model pembelajaran pembelajaran yang akan diterapkan dalam penelitian ini nantinya diharapkan bisa dijadikan salah satu model pembelajaran alternatif untuk dikembangkan di sekolah mereka. Sedangkan manfaat bagi sekolah diharapkan bahwa penelitian ini dapat digunakan sebagai pedoman meningkatkan kualitas pembelajaran Bahasa Inggris di SMP Negeri 2 Tugu Kabupaten Trenggalek dan nantinya bisa dijadikan sebagai salah satu acuan untuk mengetahui sejauh manakah keefektifan kegiatan belajar mengajar di sekolah.

Bila ditinjau dari segi etomologi atau asal usul bahasa, maka "hasol belajar adalah sebuah frase hasil belajar. dan ini merupakan bentukan dari kata "hasil" dan kata "belajar". Berdasarkan Kamus Besar Bahasa Indonesia karya WJS. Poerwodarminto (1995: 343) kata hasil adalah sesuatu yang diadakan (dibuat, dijadikan) akibat usaha.Adapun tentang kata "belajar" telah banyak ahli yang membuat definisi kata ini, seperti Slameto yang membuat definisi bahwa belajar sebagai suatu proses usaha yang dilakukan seseorang untuk memperoleh suatu perubahan tingkah laku yang baru secara keseluruhan, sebagai hasil pengalamannya sendiri dalam interaksi dengan lingkungannya (Slameto, 2010: 10). Sedangkan Sugihartono (2007: 74) mengatakan bahwa belajar merupakan proses perubahan tingkah laku sebagai hasil interaksi individu dengan lingkungannya. Sementara itu Morgan dalam buku drs. M. Ngalim Purwanto (2002: 84) mengatakan bahwa belajar adalah setiap perubahan yang relatif menetap dalam tingkah laku yang terjadi sebagai suatu hasil dari latihan atau pengalaman.

Sehingga dapat dikatakan bahwa belajar adalah suatu proses usaha yang telah dilakukan oleh seseorang dan menghasilkan perubahan tingkah laku secara keseluruhan dan relatif menetap sebagai hasil pengalaman dalam berinteraksi dengan lingkungannya. Sedangkan frase hasil belajar menurut Suratinah Tirtonegoro adalah penilaian hasil usaha kegiatan belajar yang dinyatakan dalam bentuk simbol, angka, huruf maupun narasi yang menggambarkan pencapapaian-pencapaian siswa dalam kurun waktu tertentu. Sementara itu pengertian hasil belajar menurut Dimyati dan Mujiono (2010: 61) adalah merupakan hasil suatu interaksi tindak belajar dan tindak mengajar. Dari sisi guru tindak mengajar diakhiri dengan proses evaluasi hasil belajar, sedangkan dari sisi hasil belajar merupakan berakhirnya pengajaran dari puncak proses belajar.

Sementara itu terkait dengan frase "hasil belajar" Eko Putro Widoyoko (2009:1), mengatakan bahwa hasil belajar adalah hasil belajar berhubungan dengan pengukuran, yang selanjutnya akan terjadi penilaian yang akan menuju evaluasi uang bisa berupa tes maupun non tes. Pengukuran, penilaian dan evaluasi bersifat hirarki. Evaluasi didahului dengan penilaian (assessment), sedangkan penilaian didahului dengan pengukuran. Jadi dapat disimpulkan bahwa hasil belajar merupakan pengukuran atas hasil usaha ketika 
berinteraksi yang akan menghasilkan penilaian dalam bentuk angka, simbol maupun narasi-narasi yang mendeskripsikan pencapaian-pebcapaian seseorang.

Richards and Schmidt (2002:54-55), mendefinisikan menulis adalah expressing idea, concept, feeling, opinion and experience in certain place, time and situation in written form yang artinya menulis adalah mengungkapkan ide, konsep, perasaan, pendapat dan pengalaman pada tempat, waktu dan situasi tertentu dalam bentuk tulisan. Sedangkan De Porter (2005:179) mengatakan bahwa menulis adalah aktifitas seluruh otak yang menggunakan belahan otak kanan (emosional ) dan otak kiri (logika). Adapun Akhadiah (2001:3) mendefinisikan menulis sebagai aktifitas komunikasi bahasa dan menyampaikan pesan dengan menggunakan bahasa tulisan sebagai medianya. Oshima dan Hogue dalam buku panduan PTBK (2005:100) mengatakan bahwa menulis adalah pengungkapan ide atau pokok - pokok pikiran yang dijabarkan dalam 3 bagian yaitu a) bagian pendahuluan, b) bagian isi, c) bagian penutup atau konklusi. Selain harus mempunyai isi yang sesuai, suatu tulisan harus mengikuti suatu pola pengorganisasian (form) tertentu untuk bisa disebut sebagai tulisan yang baik. Berkaitan dengan standar bentuk ini, seorang penulis perlu memperhatikan beberapa aspek formal dalam penulisan, misalnya: kerapian tulisan (neat writing), ejaan (spelling), pemenggalan (punctuation), tanda baca, tata bahasa (grammar) serta pemilihan kata (diction).

Didalam kegiatan pembelajaran menulis hendaknya dilakukan dengan terus menerus agar dapat menghasilkan kemampuan yang optimal. Untuk dapat mengetahui kemampuan siswa maka perlu diadakan pengukuran. Ada beberapa kriteria yang harus yang harus dipenuhi dalam melaksanakan pengukuran, sebagaimana yang sudah diungkapkan oleh Brown (2007: 413) yang menyebutkan ada 6 kategori dalam penilaian: (1) content: thesis statement, related ideas, development of ideas (through personal experience, illustration, fact, and opinions), use of description and consistent focus; (2) organization: effectiveness of introduction, logical sequence of ideas, conclusion, appropriate length; (3) discourse: topic sentences, paragraph unity, transitions, discourse marks, cohesion, rhetorical conventions, reference, fluency, economy, variation; (4) syntax; (5) vocabulary; (6) mechanics: spelling, punctuation..

Dalam buku Tim MGMP Bahasa Inggris Kabupaten Trenggalek dalam Buku Pendamping Siswa kelas IX mendefinisikan teks prosedur adalah teks yang berfungsi untuk memberikan petunjuk ataupun arahan tentang bagaimana cara melakukan atau membuat sesuatu (2015: 20) . Dengan adanya arahan yang tersusun secara terinci dalam teks diharapkan pembaca yang mengikuti dapat lebih mengerti. Selanjutnya juga dijelaskan tentang jenis teks procedure yang ada yaitu:a) Teks yang mengungkapkan cara mengerjakan kegiatan tertentu misalnya teks dengan judul Making Smoothie, How to Ride Safely, How to Send Picture Using Multi Media, How to Purify the Water; b) Teks yang mengungkapkan tentang penggunaan sesuatu atau manual pengoperasian suatu benda misalnya teks dengan judul How to Operate Blender, How to Cook Using Magic Com, 
How to Operate Microwave, How to Blend Frui; c)Teks yang mengungkapkan tentang hal yang berhubungan dengan tingkah laku manusia atau tips-tips kiat hidup misalnya teks dengan judul How to Gain Friends, To be Succesful in State Examination.

Di dalam setiap teks selalu ada struktur atau susunan teks dan unsur-unsur kebahasaan. Teks procedure mempunyai 3 bagian dalam susunan teksnya. Hal ini disebutkan dalam buku Materi ToT bagi Pengurus MGMP Bahasa Inggris Provinsi Jawa Timur (2006:200-203) yaitu a) tujuan atau judul yang penulisannya bisa dalam bentuk Gerund, To infinitive maupun langsung disebutkan dalam bentuk kata benda, b) bahanbahan dimana bila tentang resep atau cara membuat sesuatu disetai dengan ukuran yang jelas, dan c) langkah-langkah yang dalam penulisannya menggunakan bentuk Imperative (kalimat perintah).

Selanjutnya dijelaskan juga tentang unsur kebahasaan yang menjadi ciri teks procedur yang dirumuskan sebagai berikut: a) Penggunaan pola kalimat imperative. Kalimat perintah adalah jenis kalimat yang digunakan seperti; mash the cooked potatoes, keep smilling, turn on the power button; $b$ ) Penggunaan Action verbs; c) Connective untuk mengurutkan kegiatan, seperti: First, second, third, Firstly, secondly, before, after, next, after that, then, while dan seterusnya; d) Adverbials untuk menyatakan secara rinci tentang waktu, tempat dan cara yang akurat misalnya, for 5 minutes, two centimetres from the top, in a big dish dan lain-lain.

Model pembelajaran Scramble Text adalah salah satu model dalam pembelajaran kooperatif. Bahri Djamarah dan Aswan Zain (2006:134) mengatakan bahwa model pembelajaran Scramble adalah permainan bahasa yang pada hakekatnya adalah permainan bahasa dan merupakan suatu aktifitas untuk memperoleh ketrampilan tertentu dengan cara menggembirakan. Sedangkan menurut Kokom Komalasari (2010:84) model pembelajaran Scramble merupakan salah satu model pembelajaran yang mengajak siswa mencari jawaban terhadap suatu pertanyaan atau pasangan dari suatu konsep secara kreatif dengan cara menyusun huruf-huruf yang disusun secara acak sehingga membentuk suatu jawaban/pasangan konsep yang dimaksud. Menurut Suyatno (2009:7678) ada kekurangan dan kelebihan dalam menerapkan model pembelajaran Scrambled. Kelebihan model pembelajaran Scramble adalah :1) Setiap anggota kelompok harus bertanggung jawab atas apa yang dikerjakan kelompoknya; 2) Model pembelajaran ini dapat mengurangi sterss atau ekanan pada siswa, karena model ini memungkinkan siswa belajar sambil bermain, 3) danya kerjasama kelompok yang dapat memupuk rasa solidaritas dalam kelompok; 4) Materi dalam pembelajaran ini biasanya mengesankan dan tidak mudah dilupakan.

Adapun kekurangan dalam model pembelajaran Scramble ini adalah : 1) Guru memerlukan waktu yang lebih lama dalam membuat perencanaan perencanaan yang lebih rumit, 2) Penerapan model pembelajaran Scramble kadang gaduh sehingga bisa mengganggu kelas yang disebelahnya, 3) Terkadang butuh waktu yang lebih lama dalam 
menerapkan model Scramble dalam pembelajaran Bahri Djamarah dan Aswan Zain (2006: 90-91) telah merumuskan langkah-langkah dalam kegiatan pembelajatan dengan menggunakan model Scramble sebagai berikut: 1) Guru menyiapkan sebuah wacana, kemudian keluarkan kalimat-kalimat yang terdapat dalam wacana tersebut kedalam kartu-kartu; 2) Guru membuat kartu soal yang diacak nomornya; 3) Siswa dalam kelompok masing-masing mengerjakan soal dan mencari kartu soal yang jawabannya cocok, sebelumnya jawaban telah diacak sedemikian rupa, 4) Siswa diharuskan dapat menyusun kata jawaban yang telah tersedia dalam waktu yg ditentukan; 5) Setelah selesai pekerjaan dikumpulkan dan diperiksa.

\section{METODOLOGI PENELITIAN}

Penelitian yang akan dilaksanakan ini direncanakan dalam bentuk Classroom Action Research atau penelitian tindakan kelas karena bertujuan untuk menhatsi permasalahan yang berhubungan dengan kegiatan pembelajaran. Adapun pelaksanaannya mengacu pada rancangan Kemmis dan Taggart dalam Rochiati (2008: 66). Penelitian ini menggunakan 2 siklus dan 4 tahap yaitu a) perencanaan, b) pelaksanaan, c) pengamatan dan d) refleksi.

Subjek penelitian ini adalah siswa kelas IX A. Kelas ini mempunyai jumlah siswa 36 orang yang terdiri dari 20 siswa laki-laki dan 16 siswa perempuan. Penelitian dilaksanakan di kelas IX A dengan alasan bahwa berdasarkan kegiatan pembelajaran sehari-hari pada saat masih di kelas VIII, kelas ini termasuk kelas yang paling rendah hasil belajarnya. Selain itu dengan jumlah siswa laki-laki yang lebih banyak membuat kelas ini menjadi kelas yang cukup gaduh dalam mengikuti kegiatan pembelajaran.

Pada penelitian ini, peneliti menggunakan 1 jenis instrumen penelitian yaitu tes yang berbentuk tes tulis berupa menulis teks Procedure. Rubrik penilaian pada kegiatan ini meliputi: 1) Grammar, 2) Diction, 3) Content, dan 4) Mekanik. Adapun teknik pengumpulan data dalam kegiatan penelitian ini diperoleh dari tes uji kompetensi menulis teks procedure sedehana yang dilaksanakan di akhir pertemuan ke 2 pada masing-masing siklus.

Setelah semua data terkumpul, maka kegiatan selanjutnya adalah menganalisa untuk menentukan nilai hasil belajar dengan cara sebagai berikut:

$\mathrm{NA}=\frac{\sum S}{\sum N \max } \times 100$

Keterangan:

$\mathrm{N} \quad$ : Nilai akhir siswa

$\sum$ NS : Jumlah semua skor yang diperoleh siswa dari masing-masing komponen $\sum \mathrm{N}$ max : Jumlah nilai maksimal dari semua komponen

Langkah selanjutnya adalah menentukan nilai rata-rata tes ditentukan dengan cara sebagai berikut: 
$\mathrm{RN}=\frac{\sum N}{\sum S}$

Keterangan:

$\mathrm{RN}$ : Nilai rata-rata

$\sum \mathrm{N} \quad$ : Jumlah nilai seluruh siswa

$\sum \mathrm{S} \quad$ : Jumlah seluruh siswa

Adapun persentase ketuntasan dianalisa dengan cara sebagai berikut:

$\mathrm{PK}=\frac{\sum K}{\sum S} \mathrm{X} 100 \%$

Keterangan:

PK : Persentase ketuntasan

$\sum \mathrm{K} \quad$ : Jumlah siswa yang tuntas

$\sum \mathrm{S} \quad$ : Jumlah seluruh siswa

$100 \%$ : Standar persentase ideal

\section{HASIL PENELITIAN}

Pada tahap ini, peneliti dan kolaborator bekerja sama mempersiapkan segala perangkat yang diperlukan dalam pelaksanaan tindakan penelitian. Kegiatan tersebut diantaranya adalah:

1) Menyiapkan silabus pembelajaran bahasa Inggris KD 6.3 menulis teks Procedure melalui model pembelajaran Scramble Text dengan rancangan 2 pertemuan

2) Menyiapkan Rencana Pelaksanaan Pembelajaran (RPP) KD 6.3 menulis teks Procedure pendek sederhana melalui model pembelajaran Scramble Text. Tema pada siklus 1 adalah membuat makanan atau minuman

3) Menyiapkan student's worksheet atau Lembar Kerja Siswa (LKS) untuk 2 pertemuan

4) Menyiapkan media pembelajaran berupa potongan-potongan kalimat pada kertas yang diberi double tape, kertas duplex berukuran $20 \mathrm{~cm}$ X $30 \mathrm{~cm}$ untuk menempel kertas kecil berisi potongan kalimat

5) Mempersiapkan instrumen-instrumen yang lain seperti lembar jawaban, daftar hadir, format penilaian

\section{SIKLUS 1}

\section{Tahap Tindakan}

Sesuai yang direncakanan pelaksanaan tindakan siklus 1 pertemuan 1 pada hari Kamis tanggal 24 September 2015 pada kelas IX A jam ke 5 dan ke 6. Setelah bel berbunyi tanda berakhirnya waktu istirahat, peneliti dan kolaborator memasuki ruangan. Anak-anak dengan antusias menjawab salam peneliti. Mereka sudah diberitahu bahwa hari itu kegiatan pembelajaran akan sedikit berbeda karena ada seseorang yang akan mengamati kegiatan pembelajaran mereka. Kemudian kegiatan dilanjutkan dengan memeriksa kehadiran siswa, dan memberi sedikit motivasi pada mereka agar senantiasa rajin belajar. Setelah itu peneliti menyampaikan tujuan pembelajaran yang akan dicapai, 
bahwa mereka akan mempelajari tentang kosa kata dan unsur-unsur bahasa yang diperlukan dalam mengarang teks Procedure.

Setelah kegiatan awal selesai, peneliti melanjutkan dengan kegiatan inti dengan mereview tentang teks Procedure; kosa kata, generic structure dan fitur-fitur kebahasaan yang digunakan. Selanjutnya guru membagikan lembar kerja siswa dan meminta mereka melengkapi tabel dengan ingredients (bahan-bahab), spices (bumbu) dan action verb (kata kerja) berdasarkan teks yang diterima. Ketika semua sudah selesai guru dan siswa mendiskusikan jawaban. Selanjutnya bersama teman sebangkunya siswa membuat kalimat-kalimat imperative yang lain sesuai dengan action verb yang diperoleh pada latihan sebelumnya yang kemudian didiskusikan bersama-sama antara guru dan siswa. Guru dan siswa mendiskusikan jawaban.

Pertemuan 2 siklus 1 dilaksanakan hari Jumat tanggal 25 September 2015 pada jam ke 3 dan ke 4 . Seperti sebelumnya kegiatan pembelajaran didahului dengan kegiatan awal. Hal pertama yang dilakukan adalah mengucapkan salam, yang dilanjutkan dengan memeriksa kehadiran siswa. Setelah itu peneliti memberikan motivasi pada para siswa, dan yang teraakhir adalah menyampaikan tujuan pembelajaran padahari itu yakni menerapkan model Scramble Text dalam kegiatan latihan mengarang dan melakukan uji kompetensi mengarang teks Procedure sederhana dengan tema pengalaman menggunakan alat transportasi.

Setelah menyelesaikan kegiatan awal, maka peneliti melakukan kegiatan inti dengan kembali mendiskusikan kembali tentang teks procedure, unsur-unsur kebahasaan, tujuan komunikatif dan struktur teks. Selanjutnya guru membentuk kelompok yang terdiri dari 4 siswa. Setelah semua duduk berkelompok guru membagi 1 kertas karton dan 1 amplop berisi potongan-potongan kalimat sebuah teks procedure. Setiap kelompok menempel potongan teks yang diterima pada kertas karton yang diterima sehingga menjadi satu teks procedure yang benar. Ketika semua sudah selesai guru dan siswa mendiskusikan jawaban.

Kegiatan selanjutnya guru membagikan Lembar Kerja yang baru kepada setiap kelompok. Bersama kelompoknya siswa membuat teks Procedure sederhana berdasarkan gambar yang diterima dengan struktur teks yang lengkap. Kemudian guru dan siswa mendiskusikan jawaban. Setelah tidak ada pertanyaan lagi guru meminta siswa mengerjakan uji kompetensi menulis teks Procrdure pendek berdasarkan pengalaman pribadi. Tepat pukul 9.40 bel tanda istirahat berbunyi, peneliti dan kolaborator meninggalkan ruangan setelah sebelumnya melakukan kegiatan penutup yaitu menanyakan kesulitan-kesulitan yang dihadapi para siswa ketika mengikuti kegiatan pembelajaran dan mengajak para siswa untuk menyimpulkan materi yang sudah dibahas pada hari itu lalu. Kemudian menyampaikan rencana kegiatan untuk pertemuan berikutnya

\section{Tahap Pengamatan}

Kegiatan pengamatan ini yang dilakukan bersamaan dengan pelaksanan tindakan ini bertujuan untuk mengamati proses tindakan dan dampak dari pemberian tindakan. Kolaborator melakukan pengamatan terhadap jalannya proses pembelajaran untuk kemudian diinformasikan pada peneliti agar pembelajaran semakin baik. Kegiatan pengamatan difokuskan pada kegiatan inti dalam RPP. 
Berdasarkan pengamatan kolaborator, pada saat pertemuan 1 semua bisa berjalan lancar. Tetapi pada saat penerapan model pembelajaran Scramble Text terlihat beberapa kelompok agak kebingungan, apalagi kelompok 3. Kelompok ini terlihat tidak padu, mereka tidak terlalu bagus dalam bekerja sama. Pada saat siswa harus menempelkan potongan-potongan kalimat, beberapa kelompok agak kebingungan, tetapi kelompok 3 terlihat yang paling bingung tdak tahu mana yang harus ditempel dahulu. Masalah lain yang timbul adalah pada saat siswa harus mendiskusikan pekerjaan mereka, beberapa siswa terlihat kurang memperhatikan karena jenis teksnya hanya 2 dan tidak bergambar.

\section{Tahap Refleksi}

Setelah menyelesaikan pertemuan 2 pada siklus 1 kolaborator dan peneliti segera melakukan kegiatan analisa data. Hasil uji kompetensi menulis teks Procedure. Keberhasilan mereka dalam mengerjakan tugas individu menulis teks Procedure dapat diketahui dari tabel berikut ini:

Tabel 1. Hasil Tes Uji Kompetensi Siklus 1

\begin{tabular}{|c|c|c|c|c|}
\hline No & Nilai & Frekuensi & Persentase & Keterangan \\
\hline 1 & 100 & 0 & 0 & - \\
\hline 2 & 95 & 2 & 5,56 & Tuntas \\
\hline 3 & 90 & 3 & 8,33 & Tuntas \\
\hline 4 & 85 & 4 & 11,11 & Tuntas \\
\hline 5 & 80 & 4 & 11,11 & Tuntas \\
\hline 6 & 75 & 6 & 16,67 & Tuntas \\
\hline 7 & 70 & 7 & 19,44 & Tuntas \\
\hline 8 & 65 & 3 & 8,33 & Tidak Tuntas \\
\hline 9 & 60 & 3 & 8,33 & Tidak Tuntas \\
\hline 10 & 55 & 4 & 11,11 & Tidak Tuntas \\
\hline \multicolumn{2}{|c|}{ Jumlah } & 36 & 100 & - \\
\hline \multicolumn{2}{|c|}{ Rata-rata } & 73,75 & - & - \\
\hline \multicolumn{2}{|c|}{ Ketuntasan } & 26 & 72,22 & - \\
\hline \multicolumn{2}{|c|}{ Ketidaktuntasan } & 10 & 27,78 & - \\
\hline
\end{tabular}

Dari tabel diatas dapat diketahui peningkatan yang terjadi setelah peneliti menerapkan model pembelajaran Scramble Text pada Kompetensi Dasar 6.3 menulis teks Procedure sederhana pada kelas IX A semester 1 SMP Negeri 2 Tugu tahun pelajaran 2015/2016. Salah satu peningkatan yang yang terjadi adalah nilai rata-rata kelas yang semula 63,89 pada saat pra siklus, menjadi 73,75 setelah siklus 1. Akan tetapi walapun sudah ada peningkatan yang berarti, hasil penelitian siklus 1 ini masih dibawah target yang ditetapkan. Target untuk nilai rata-rata adalah 75,00. persentase ketuntasan hasil belajar menulis.

Begitu pula dengan persentase siswa yang tidak tuntas berkurang dari 16 atau $44,44 \%$ pada saat pra siklus menjadi 10 siswa atau $27,78 \%$. Sedangkan siswa yang tuntas meningkat menjadi 26 siswa atau 72,22\% padahal kondisi pada saat pra siklus adalah 55,56\% atau 20 siswa dari 36. Sehingga kalau digambarkan dalam diagram persentase ketuntasan adalah seperti pada diagram 4.1 berikut ini. 
Walaupun ketuntasan klasikal sudah meningkat, tetapi capaian ini masih dibawah target yang ditetapkan untuk persentase ketuntasan secara klasikal adalah 75\%. Demikian paian nilai rata-rata kelas yang masih dibawah target yakni 75.. Untuk itu kolaborator dan peneliti memutuskan bahwa penelitian tindakan kelas akan dilanjutkan ke siklus 2 .

Selain menganalisa perolehan data, kolaborator dan peneliti juga mendiskusikan hasil pengamatan yang dilakukan oleh kolaborator. Dari hasil diskusi ada beberapa hal yang diusulkan oleh kolaborator, diantaranya adalah:

a. Mengganti tema pada siklus 2 dengan tema cara mengoperasikan technologi ringan

b. Mengganti anggota kelompok 3 karena ada 3 anggota yang nilainya dibawah KKM dengan kelompok 2 yang anggotanya tuntas semua

c. Menambah jumlah teks yang digunakan pada saat menerapkan model Scramble Text.

d. Memberi gambar agar siswa tidak terlalu bingung dalam menempelkan kalimat.

\section{SIKLUS 2}

\section{Tahap Perencanaan}

Pada tahap ini, peneliti dan kolaborator bekerja sama memperbaiki perangkat yang diperlukan dalam mlanjutkan pelaksanaan tindakan penelitian pada siklus 2 . Kegiatan tersebut diantaranya adalah:

1) Mengganti tema pada RPP menjadi tema tentang cara mengoperasikan pelaratan technology sederhana (light technology)

2) Mengganti student's worksheet atau Lembar Kerja Siswa (LKS) untuk siklus 2 dengan tema yang disesuaikan dengan RPP

3) Mengubah media pembelajaran dengan mengganti kalimat pada potongan-potongan kertas yang diberi double tape dan memberi tambahan gambar pada kertas duplex berukuran $20 \mathrm{~cm}$ X $30 \mathrm{~cm}$ yang digunakan untuk menempel kertas kecil beisi potongan kalimat

4) Mempersiapkan instrumen-instrumen yang lain seperti lembar jawaban, daftar hadir, format penilaian

\section{Tahap Tindakan}

Pelaksanaan tindakan pada siklus 2 pertemuan 1 sesuai dengan rencana awal yakni hari Kamis tanggal 08 Oktober 2015 masih pada kelas yang sama kelas IX A jam ke 5 dan ke 6. Peneliti dan kolaborator memasuki ruangan setelah bel tanda berakhirnya waktu istirahat berbunyi. Anak-anak masih dengan antusiasme yang sama dalam menjawab salam peneliti. Mereka sudah diberitahu bahwa hari itu kegiatan pembelajaran akan mengulangi lagi kegiatan yang sudah mereka lakukan sebelumnya dengan ditambah perbaikan yang akan membantu mereka dalam memahami Kompetensi Dasar menulis.

Kemudian kegiatan dilanjutkan dengan memeriksa kehadiran siswa, dan memberi sedikit motivasi pada mereka agar senantiasa bersemangat. Setelah itu peneliti menyampaikan tujuan pembelajaran yang akan dicapai, bahwa mereka akan mempelajari 
tentang kosa kata dan unsur-unsur bahasa yang diperlukan dalam mengarang teks Procedure yang pada hari itu tema yang akan digunakan adalah light technology.

Setelah kegiatan awal selesai, peneliti melanjutkan dengan kegiatan inti dengan mereview tentang teks procedure, kosa kata yang digunakan, generic structure dan fiturfitur kebahasaan teks prosedur. Kemudian guru membagikan lembar kerja siswa dan meminta siswa memberi nama benda-benda tentang alat-alat elektronik yang ada pada task 1. Ketika semua sudah selesai mengerjakan guru dan siswa mendiskusikan jawaban. Selanjutnya siswa menjodohkan kata pada kolom A dengan lawan kata pada kolom B bersama teman sebangkunya. Guru dan siswa mendiskusikan jawaban. Selanjutnya guru memberitahukan perubahan kelompok. Sa; ah satu anggota kelompok 3 yang nilainya dibawah KKM pindah ke kelompok 2. Secara berkelompok siswa membuat kalimatkalimat perintah berdasarkan tugas sebelumnya pada task 2. Guru dan siswa mendiskusikan jawaban

Pukul 11.20 menit bel berbunyi tanda jam ke 6 sudah selesai. Peneliti mengajak para siswa untuk menyimpulkan materi yang sudah dibahas pada hari itu. Selanjutnya peneliti menanyakan kesulitan-kesulitan yang dihadapi para siswa ketika mengikuti kegiatan pembelajaran. Dan yang terakhir adalah menyampaikan rencana kegiatan untuk pertemuan berikutnya. Setelah itu peneliti dan kolaborator meninggalkan ruang setelah sebelumnya mengucapkan salam.

Pertemuan 2 siklus 2 dilaksanakan hari Jumat tanggal 08 April 2015 pada jam ke 3 dan ke 4. Seperti sebelumnya kegiatan pembelajaran didahului dengan kegiatan awal. Hal pertama yang dilakukan adalah mengucapkan salam, yang dilanjutkan dengan memeriksa kehadiran siswa. Setelah itu peneliti memberikan motivasi pada para siswa, dan yang terakhir adalah menyampaikan tujuan pembelajaran pada hari itu yakni menerapkan model Scramble Text dalam kegiatan latihan mengarang dan melakukan uji kompetensi mengarang teks Procedure tentang cara mengoperasikan sesuatu

Setelah menyelesaikan kegiatan awal, maka peneliti melakukan kegiatan dengan meminta siswa duduk bersama kelompoknya. Selanjutnya guru membagi 1 kertas karton dan 1 amplop berisi potongan-potongan teks tentang cara mengoperasikan sesuatu. Ada 3 macam media gambar berseri, 3 kelompok akan memegang LK yang berisi teks yang sama. Setiap kelompok menempel potongan teks yang diterima pada kertas karton yang diterima sehingga menjadi satu teks Procedure yang benar. Ketika semua sudah selesai guru dan siswa mendiskusikan jawaban dengan meminta salah satu anggota untuk mempresentasikan hasil diskusi kelompok. Selanjutnya guru membagikan Lembar Kerja yang baru. Bersama kelompoknya siswa menyusun kaliat yang acak menjadi 1 teks Procedure yang benar. Guru dan siswa mendiskusikan jawaban. Dan yang terakhir siswa mengerjakan uji kompetensi menulis teks Procedure pendek .

Tepat pukul 9.40 bel tanda istirahat berbunyi, peneliti dan kolaborator meninggalkan ruangan setelah sebelumnya melakukan kegiatan penutup yaitu mengajak para siswa untuk menyimpulkan materi yang sudah dibahas pada hari itu lalu menanyakan 
kesulitan-kesulitan yang dihadapi para siswa ketika mengikuti kegiatan pembelajaran. dan yang terakhir adalah menyampaikan rencana kegiatan untuk pertemuan berikutnya.

\section{Tahap Pengamatan}

Kegiatan pengamatan ini yang dilakukan bersamaan dengan pelaksanan tindakan ini bertujuan untuk mengamati proses tindakan dan dampak dari pemberian tindakan. Hasil belajar siswa dari tes siklus 2 dianalisa dan dideskripsikan untuk menggambarkan peningkatan hasil belajar siswa. Kolaborator melakukan pengamatan terhadap jalannya proses pembelajaran untuk kemudian diinformasikan pada peneliti agar pembelajaran semakin baik. Kegiatan pengamatan difokuskan pada kegiatan inti dalam RPP.

Seperti pada saat siklus 1, pertemuan 1 siklus 2 ini tidak ada catatan-catatan khusus dalam pelaksanaan tindakan, karena semua berjalan lancar. Begitu pula dengan permasalahan yang muncul pada saat pertemuan 2 siklus 1 ketika siswa harus menempelkan potongan-potongan kalimat pada kertas duplex sudah tidak tampak lagi. Mereka terlihat lebih lancar, karena ada rangkaian gambar yang harus mereka perhatikan sebagai petunjuk dalam merangkaikan kalimat. Pergantian kelompok uang dilakukan pada kelompok 3 membuat kelompok ini menjadi lebih baik dalam bekerjasama.

\section{Tahap Refleksi}

Setelah menyelesaikan pertemuan 2 siklus 2, kolaborator dan peneliti segera melakukan kegiatan analisa data. Hasil uji kompetensi menulis teks Procedure pada siklus 2 dengan tema cara mengoperasikan sesuatu telah menunjukkan adanya peningkatan bila dibandingkan dengan saat siklus 1. Peningkatan hasil belajar siswa kelas IX A semester 1 tahun pelajaran 2015/2016 dapat diketahui dari tabel 2 berikut ini:

Tabel 2. Hasil Tes Uji Kompetensi Siklus 2

\begin{tabular}{|c|c|c|c|c|}
\hline No & Nilai & Frekuensi & Persentase & Keterangan \\
\hline 1 & 100 & 2 & 5,56 & Tuntas \\
\hline 2 & 95 & 3 & 8,33 & Tuntas \\
\hline 3 & 90 & 4 & 11,11 & Tuntas \\
\hline 4 & 85 & 4 & 11,11 & Tuntas \\
\hline 5 & 80 & 6 & 16,67 & Tuntas \\
\hline 6 & 75 & 7 & 19,44 & Tuntas \\
\hline 7 & 70 & 7 & 19,44 & Tuntas \\
\hline 8 & 65 & 2 & 5,56 & Tidak Tuntas \\
\hline 9 & 60 & 1 & 2,78 & Tidak Tuntas \\
\hline \multicolumn{2}{|c|}{ Jumlah } & 35 & 100 & \\
\hline \multicolumn{2}{|c|}{ Rata-rata } & 73 & 79,72 & \\
\hline \multicolumn{2}{|c|}{ Ketuntasan } & 33 & 91,67 & \\
\hline \multicolumn{2}{|c|}{ Ketidaktuntasan } & 3 & 8,33 & \\
\hline
\end{tabular}

Dari tabel di atas dapat diketahui peningkatan hasil belajar kelas IX A setelah berakhirnya siklus 2 . Salah satunya adalah perolehan nilai rata-rata siswa. Bila pada siklus 
1 perolehan nilai rata-rata siswa sebesar 73,75 maka pada siklus 2 perolehan nilai ratarata meningkat menjadi 79,72 .

Demikian pula dengan ketidaktuntasan yang menurun drastis, pada saat siklus 1 jumlah siswa yang tidak tuntas adalah 10 siswa atau 27, 28\% pada saat siklus 2 berkurang menjadi 3 siswa atau 8,33\%. Sedangkan jumlah siswa yang berhasil mencapai atau melampaui nilai KKM meningkat dari 26 siswa menjadi 33 dari 36 siswa. Kalau dipersentasekan menjadi $91,67 \%$ siswa yang tuntas.

Hasil akhir dari penelitian tindakan kelas ini adalah adanya peningkatan hasil belajar siswa dalam pembelajaran menulis teks Procedure sederhana dengan menggunakan model pembelajaran Scramble Text pada siswa kelas IX A semester 1 SMP Negeri 2 Tugu tahun pelajaran 2015/2016. Adapun peningkatan hasil belajar kelas IX A SMP Negeri 2 Tugu dalam menulis teks Procedure setelah menerapkan model pembelajaran Scramble Text mulai pra siklus, siklus 1 dan siklus secara lengkap dapat dilihat dari tabel 3 berikut ini:

Tabel 3. Peningkatan Prestasi belajar Siswa

\begin{tabular}{|l|l|c|c|c|}
\hline No. & \multicolumn{1}{|c|}{ Aspek } & Pra Siklus & Siklus 1 & Siklus 2 \\
\hline 1. & Rata-Rata & 63,89 & 73,75 & 79,72 \\
\hline 2. & Ketuntasan & $55,56 \%$ & $72,22 \%$ & $91,67 \%$ \\
\hline 3. & Ketidaktuntasan & $44,44 \%$ & $27,28 \%$ & $8,33 \%$ \\
\hline 4. & Nilai Tertinggi & 80 & 95 & 100 \\
\hline 5. & Nilai Terendah & 45 & 55 & 60 \\
\hline
\end{tabular}

Dari tabel diatas dapat diketahui bahwa setelah menerapkan model pembelajaran Scramble Text pada kelas IX A semester 1 SMP Negeri 2 Tugu tahun pelajaran 2015/2016 mengalami peningkatan. Rata-rata nilai hasil belajar pada saat prasiklus adalah 63,89 dan pada siklus 1 meningkat menjadi 73,75 kemudian pada siklus 2 meningkat lagi menjadi sebesar 79,72.

Begitu pula dengan peningkatan persentase ketuntasan kelas. Persentase pada saat prasiklus adalah 55,56\% atau 20 siswa dari 36 siswa. Pada saat siklus 1 persentase ketuntasan kelas meningkat menjadi $72,22 \%$ atau 26 siswa dari 36 siswa dan pada siklus 2 meningkat menjadi $91,67 \%$ atau 33 siswa. Sementara itu jumlah siswa yang tidak tuntas terus mengalami penurunan. Kondisi pada saat pra siklus adalah 16 siswa atau 44,44 \%, pada saat siklus 1 menjadi 10 siswa atau 27,28 \% Dan pada saat siklus 2 jumlah siswa yang tidak tuntas tinggal 3 siswa atau 8,33\%.

Apabila dikonversikan pada grafik perbandingan maka hasil belajar tersebut tergambar pada gambar berikut ini. 


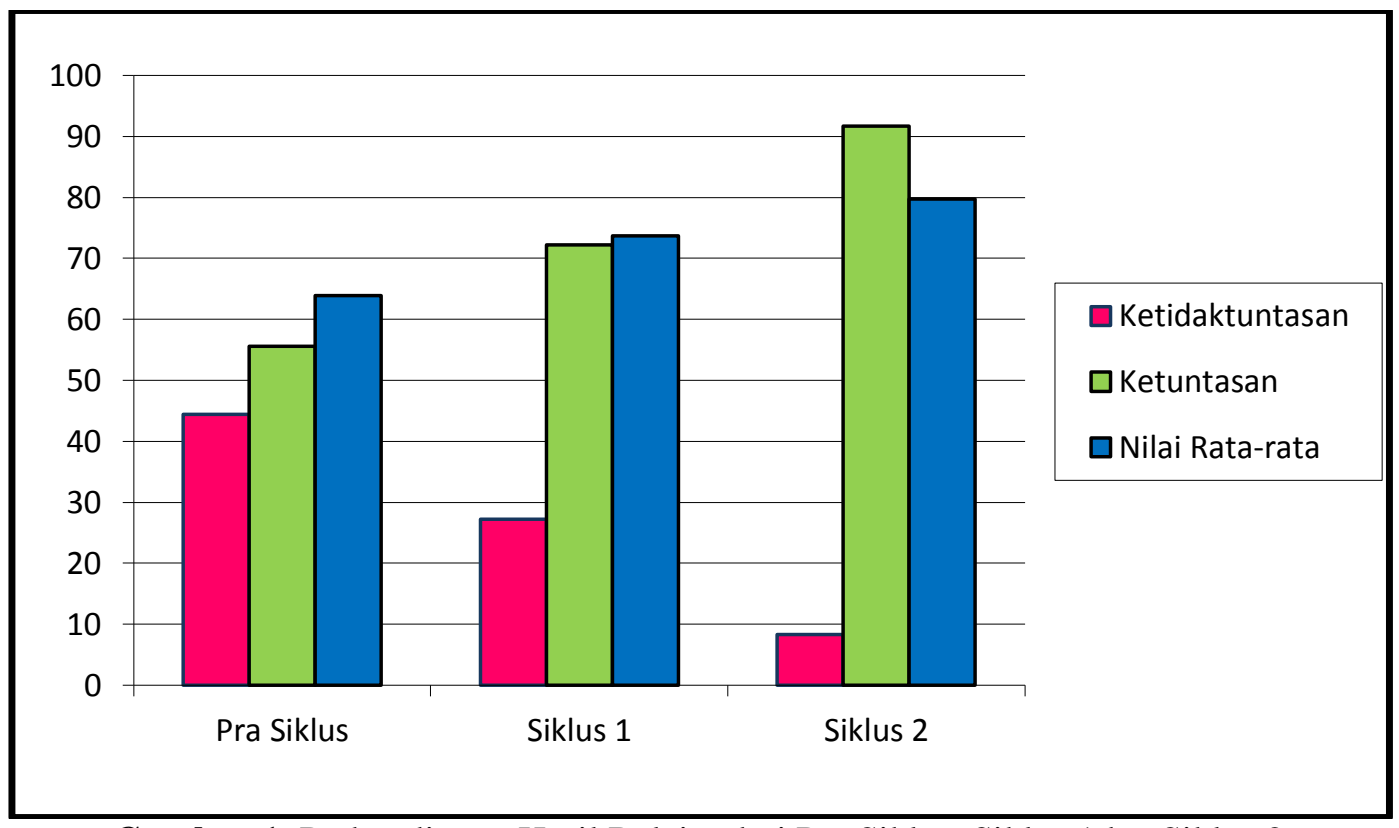

Gambar 1. Perbandingan Hasil Belajar dari Pra Siklus, Siklus 1dan Siklus 2

Dari grafik diatas terlihat perkembangan nyata mulai dari kondisi pada saat pra siklus, siklus 1 hingga siklus 2, rentang persentase siswa yang belum tuntas (warna merah muda) pada saat pra siklus sebesar 44,44\%, berkurang pada siklus 1 menjadi 27,78\% dan berkurang lagi menjadi $8,33 \%$ pada siklus 2 . Warna hijau melambangkan persentase siswa yang sudah tuntas, pada saat pra siklus 55,56\% dan pada saat siklus $172,22 \%$ dan pada siklus 2 meningkat lagi menjadi 91,67 \%. Sedangkan warna biru adalah lambang dari perkembangan nilai rata-rata hasil belajar siswa, yang capaian mereka pada saat pra siklus sebesar 63,89. Hasil ini meningkat pada siklus 1 sebesar 73,75, dan pada saat siklus 2 nilai rata-rata sebesar 79,72. Selanjutnya dari tabel 3 apabila digambarkan perkembangan perolehan nilai siswa dapat digambarkan sebagaimana berikut ini

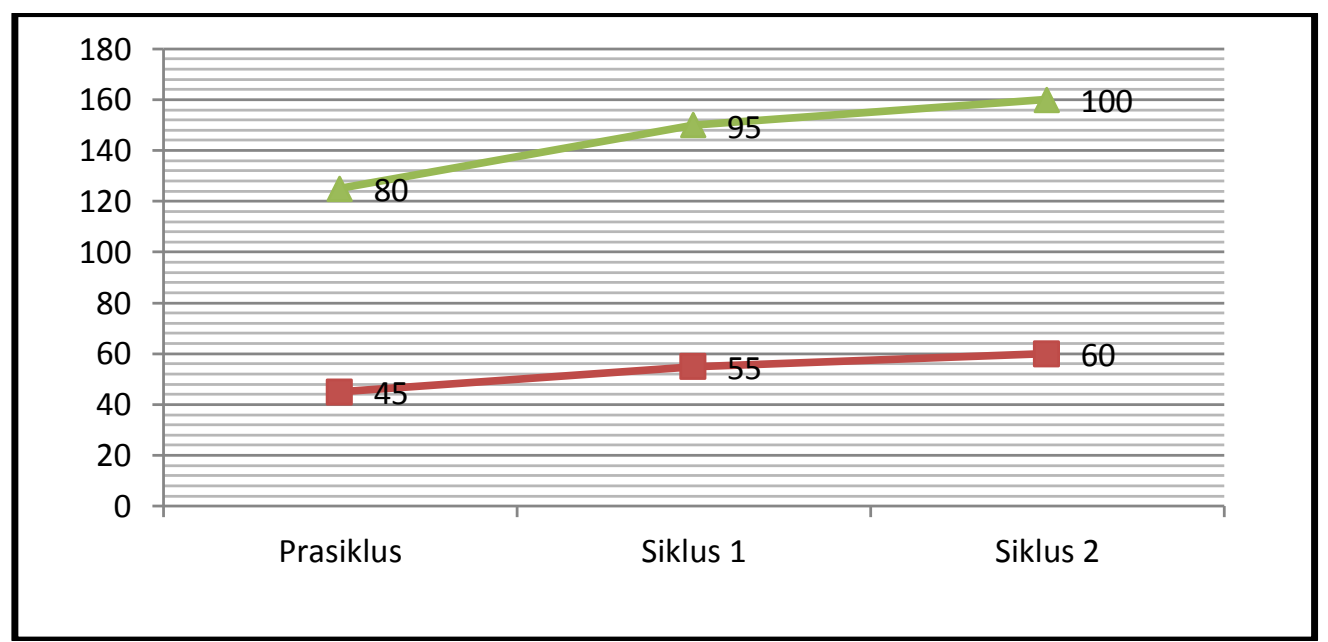

Gambar 2. Perkembangan hasil belajar siswa 
Garis hijau adalah perkembangan nilai tertinggi. Kondisi pra siklus perolehan nilai tertimggai adalah 80. Pada saat siklus 1 nilai tertinggi yang diperoleh siswa adalah 95 . Dan pada siklus 2 ada 2 siswa yang bisa memperoleh nilai sempurna 100. Selain itu nilai terendah (garis merah) yang muncul juga menjadi semakin tinggi. Bila pada pada pra skilus nilai 45 adalah nilai terendah, maka pada siklus 1 nilai terendah yang diperoleh siswa adalah 55. Sedangkan pada siklus 2 nilai terendah siswa semakin meningkat yaitu 60 .

\section{KESIMPULAN DAN SARAN}

\section{Kesimpulan}

Berdasarkan hasil tes siklus 1 dan 2 pada penelitian tindakan kelas ini, maka dapat disimpulkan bahwa hasil ini sudah memenuhi target yang ditentukan, artinya penelitian tindakan kelas di Kelas IX A SMP Negeri 2 Tugu Kabupaten Trenggalek semester 1 tahun pelajaran 2015/2016 dalam menulis Procedure Bahasa Inggris melalui model pembelajaran Scramble Text telah berhasil.

\section{Saran}

Berdasarkan pembahasan dan simpulan di atas, peneliti menyarankan agar:

1. Guru dapat berperan menjadi motivator serta dapat mengembangkan kreatifitas dalam kegiatan pembelajaran sehingga dapat meningkatkan hasil belajar siswanya

2. Guru hendaknya dapat menerapkan berbagai pendekatan dan model pembelajaran sehingga proses kegiatan pembelajaran yang dilakukan menejadi lebih variatif dan menyenangkan .

3. Guru dapat mengunakan model pembelajaran Scramble Text ini sebagai salah alternatif dalam mengatasi permasalahan yang muncul pada saat proses kegiatan pembelajara

\section{DAFTAR RUJUKAN}

Akhadiah, Subarti. 1997. Menulis, Depdikbud. Jakarta: Balai Pustaka.

Brown, H. Douglash. 2007. Teaching by Principle an Alternative Approach to Language Pedagogy (second edition). San Francisco State University

Departemen Pendidikan Nasional: 2005 Materi Pelatihan Terintegrasi Berbasis Kompetensi Bahasa Inggris, Jakarta: Departemen Pendidikan Nasional

Dimyati dan Mujiono, 2010: Belajar dan Pembelajaran. Jakarta PT Rineka Cipta

Dirjen Peningkatan mutu pendidik dan kependiikan LPMP Jawa Timur: 2006 Materi ToT Bagi Pengurus MGMP Bahasa Inggris Jawa Timur, Jakarta: Departemen 
Pendidikan Nasional

Djamarah, Bahri dan Zain Aswan, 2006. Strategi Belajar Mengajar. Jakarta.PT Rineka Cipta

Kokom. 2010. Pembelajaran Kontekstual (Konsep dan Aplikas). Bandung: Refika Aditama.

Mulyasa, E. M.Pd, Dr, 2005, Implementasi Kurikulum 2004 . Bandung, PT Remaja Rosdakarya

Poerwadarminto, W.J.S. 1995. Kamus Umum Bahasa Indonesia. Jakarta: Balai Pustaka.

Purwanto Ngalim, M. drs. 2002. Prinsip-prinsip dan Teknik Evaluasi Pengajaran. Bandung: Remaja Rosdakarya

Richards, J. C and Schmidt: (2002). Dictionary of Language Teaching and Applied Linguistics . USA: Pearson Educational Limited.

Slameto. 2010: Belajar dan Faktor-Faktor yang Mempengaruhinya. Jakarta: Rineka Cipta.

Sugihartono, dkk. 2007: Psikologi Pendidikan. Yogyakarta: Uny Press

Suyatno, 2009: Menjelajah Pembelajaran Inovatif. Jakarta. Mas Media Buana

Tim MGMP Kabupaten Trenggalek. 2015: Buku Pendamping Kelas IX. Tulung Agung. Grafika Agung Press

Tirtonegoro, Suratinah. 2001: Penelitian Hasil Belajar Mengajar. Surabaya: Usaha Nasional.

Widoyoko, Eko Putro S. 2009: Evaluasi Program Pembelajaran. Yogyakarta: Pustaka Pelajar.

Wiriaatmadja, Rochiati 2008. Metode Penelitian Tindakan Kelas untuk Meningkatkan Kinerja Guru dan Dosen. Bandung: Remaja Rosdakarya. 